\title{
ANALISIS PERDA NO 13 TAHUN 2003 TENTANG APBD SEBAGAI FAKTOR KRIMINOGEN DALAM TINDAK PIDANA KORUPSI OLEH ANGGOTA DPRD SURAKARTA PERIODE 1999 - 2004
}

\author{
Ismunarno
}

\begin{abstract}
This study aims to determine whether Perda could be kriminogen facts in a corruption and identify the location of the fault of the parties involved in relation to the regulation if it is based on Law no. 31 of 1999 Jo Law. 20 of 2001 on the eradication of corruption. This study is a descriptive normative nature. This research included literature research therefore examines only secondary data. Based on the research result that Perda No. 13 of 2003 on budget is an amendment to the budget previously provided for in Regulation No. 1 of 2003. Changes made include sector budget: Education, Culture, Belief in God Almighty, Youth and Sports (budget increase), Population and Family Welfare (Budget derived), Health (Budget falls), Housing and settlement lowered (Budget falls), Recurrent Parliament (Budget rises), Welfare (Budget falls), Travel allowance legislators (budget increase), Shopping goods (Articles ride). From the description above indicates that the changes are more likely to benefit / for the personal benefit of the members of Parliament, because of budget increases are related to the interests of members of parliament. Perda No 13 out 2003 on the budget that alter the law No. 1 Year 2003 there Kriminogen factor which is the act of corruption in particular violates Article 2 (1) and Article 3 of Law no. Jo 31 of 1999 Law No. 20 of 2001 on corruption because of errors in the process of changing the budget and the lack of legal basis as well as budget expenditures in the determination of certain sectors as described. From this research are expected to provide input on efforts that can be done to minimize corruption, especially by the executive and legislative branches in the region rose sharply as the enactment of local autonomy.
\end{abstract}

Keywords : Perda, APBD, Kriminogen, Corruption

\section{A. Pendahuluan}

Amandemen Ketiga Undang-Undang Dasar (UUD) 1945 Bab I Pasal 1 (3), bahwa Negara Indonesia adalah Negara Hukum. Artinya bahwa Indonesia adalah negara yang berdasar atas hukum (rechtstaat), tidak berdasar atas kekuasaan (machtstaat), dan pemerintahan berdasarkan atas sistem konstitusi (hukum dasar), bukan absolutism. Penegasan tersebut mengandung pengertian bahwa penyelenggaraan Negara Republik Indonesia harus dilakukan berdasarkan kaidah-kaidah hukum yang bersumber kepada konstitusi. Penyelenggaraan negara dan pembangunan tidak boleh dilakukan berdasar atas kekuasaan belaka. Dalam kerangka pengertian ini, maka hukum mempunyai dua peran utama dalam penyelenggaraan negara. Pertama, sebagai sarana untuk menjaga ketertiban dan menyelenggarakan kesejahteraan menuju terbentuknya manusia Indonesia yang serasi, selaras, dan seimbang antara lahiriah dan batiniah. Kedua, sebagai sarana untuk menjalankan pembangunan nasional dalam rangka mencapai tujuan bernegara. Dengan peran yang sangat strategis dan signifikan tersebut, hukum harus menunjukkan supremasinya baik dalam menjaga ketertiban dalam kehidupan bermasyarakat, Yustisia Vol.1 No.1 Januari - April 2012 berbangsa maupun dalam mengendalikan kegiatan penyelenggaraan negara dalam arti luas untuk mewujudkan tujuan bernegara sebagaimana tercantum dalam Pembukaan UUD 1945.

Kebijakan pembangunan nasional sebagaimana dituangkan dalam Undang- Undang Nomor 25 Tahun 2004 Tentang Perencanaan Pembangunan Nasional, salah satu program utama dalam pembangunan hukum nasional adalah program penuntasan kasus korupsi, kolusi dan nepotisme serta pelanggaran HAM. Sasaran dari program ini adalah menuntaskan kasus KKN dan Pelanggaran HAM yang belum terselesaikan secara hukum

Krisis ekonomi internasional yang melanda sejumlah negara berkembang baik di Benua Asia maupun di Benua Amerika seperti Brasil, Argentina dan negara-negara latin lainnya. Krisis di Asia Tenggara juga dialami negara Thailand, Filiphina, Singapura, Malaysia dan juga Indonesia. Malaysia negara tetangga Indonesia yang juga terpuruk perekonomiannya sudah bisa keluar dari krisis ekonominya dengan melakukan program pemulihan stabilitas ekonomi dalam waktu relatif lebih cepat, hal ini dapat dilihat dari indikator nilai tukar ringgit Malaysia terhadap Analisis Perda No 13 Tahun... 
rupiah yang tinggi sehingga menjadi primadona para tenaga kerja Indonesia untuk memburu ringgit. Mereka lebih berhasil menjalankan program pemulihan dampak krisis ekonomi karena meletakkan kepercayaan akan pemerintahan yang bersih dan gerakan pemberantasan korupsi tak mengenal pandang bulu, serta pembenahan manajemen pemerintahan menuju pemerintahan yang bersih (clean governance) dan pemerintahan yang efisien.

Reformasi yang selama ini dijalankan belum memuaskan terutama hasilnya terbukti dari adanya KNN yang masih saja menjamur baik dalam dunia pendidikan, birokrasi, pemerintahan, politik, dll. Perubahan yang terjadi lebih didominasi dari sektor politik (uphoria pemilu) yang berhasil memilih para wakil rakyat namun hasilnya belum dapat merubah kondisi lama menjadi lebih baik tetap saja sektor ekonomi yang terpuruk dan korupsi merajalela dimana-mana apalagi dilakukan oleh para anggota dewan sendiri. Upaya untuk memulihkan kepercayaan rakyat dan masyarakat luar negeri melalui penegakan hukum merupakan suatu yang tidak bisa ditawar-tawar dalam rangka partisipasi masyarakat untuk keberhasilan pembangunan maupun investasi dari luar negeri.

Dengan diundangkannya UU No. 22 Tahun 1999 yang kemudian disempurnakan dengan Undang-Undang No. 32 Tahun 2004 Indonesia memasuki era otonomi daerah yang seluas-luasnya dalam wadah NKRI. Indonesia menganut sistem otonomi riil. Sistem otonomi riil ini merupakan sistem penyerahan urusan atau tugas dan kewenangan kepada daerah didasarkan pada faktor yang nyata atau riil, sesuai dengan kebutuhan dan kemampuan yang riil dari daerah maupun pemerintah pusat serta pertumbuhan masyarakat yang menjadi daerah otonom boleh menyelengarakan semua urusan di luar yang dimiliki Pemerintahan Pusat (open and arrangement atau general competence). Kenyataan dalam praktek penyelenggaraan pemerintahan daerah, dana untuk kegiatan pribadi, dan lain-lain yang tentu saja merugikan keuangan daerah dan kepentingan masyarakat yang lain sehubungan dengan terbatasnya anggaran.

Kesemua ini menyebabkan kerugian uang negara yang tidak sedikit (milyaran rupiah). Dana yang seharusnya dialokasikan untuk pembangunan dan peningkatan stabilitas ekonomi rakyat yang baru saja terkena dampak krisis ekonomi dihabiskan untuk hal-hal yang kurang manfaatnya. Mereka tidak memperhatikan nasib rakyat kecil yang susah dalam mencari nafkah sehari-hari. Pada akhir masa pemerintahan mantan Presiden Megawati Soekarno Putri akan berakhir barulah perbuatan korupsi yang selama ini berjalan dan terkesan dibiarkan mulai diadili.
Sebagai contoh adalah penegakan hukum di Sumatra Barat yang berani melakukan pemeriksaan korupsi APBD Propinsi Sumatra Barat yang dilakukan mantan pemimpin dan anggota DPRD Sumatra Barat Periode 1999-2004, bahkan di tingkat banding para terdakwa dijatuhi hukuman lebih berat oleh Pengadilan Tinggi Padang.

Penegakan hukum khususnya terhadap para koruptor di Sumatra Barat merupakan awal/titik tolak pemberantasan korupsi. Untuk daerah setelah itu menyusul diperiksanya korupsi yang melibatkan Bupati dan anggota DPRD di berbagai kabupaten dan kotamadya di Indonesia. Dari analisa peneliti merebaknya/meningkatnya kasus korupsi di daerah tidak terlepas dari meningkatnya kewenangan yang diberikan kepada eksekutif dan legislatif di daerah melalui otonomi daerah (Power tends to corrupt absolut power corrupt absolutly). Penegakan hukum dengan menjatuhkan hukuman kepada para eksekutif/legislatif di daerah yang melakukan korupsi adalah merupakan salah satu cara untuk meminimalisir terjadinya tindak pidana ini, disamping diperlukan upaya- upaya lain untuk mencegah terjadinya tindak pidana korupsi.

Korupsi dalam kaitannya dengan APBD adalah merupakan sebagian dari contoh banyak kasus korupsi yang merebak setelah dikeluarkannya Undang - Undang tentang Otonomi Daerah, yang member kewenangan yang luas kepada daerah untuk mengatur rumah tangga sendiri yang antara lain dengan mekanisme penyusunan APBD dan pelaksanaannya dengan kata lain penyusunan APBD merupakan pintu masuk terjadinya korupsi sistemik oleh eksekutif dan legislatif oleh karena saling interdependensi antara kedua lembaga ini. Eksekutif membutuhkan legislative untuk pengesahan produk-produk aturan di daerah ( salah satunya tentang APBD) sebaliknya legislatif juga membutuhkan eksekutif karena mereka yang memegang anggaran dan juga menyusunnya.

\section{B. Tinjauan Pustaka}

\section{Tinjauan Tentang Otonomi Daerah}

Berbicara tentang otonomi daerah adalah konsekuensi dari sistem desentralisasi yang kita anut, desentralisasi adalah penyerahan kewenangan pemerintah pusat kepada daerah untuk menyelenggarakan fungsifungsi pemerintah di daerah. Sesuai ketentuan Pasal 1 butir 7 Undang-Undang Nomor 32 Tahun 2004 tentang Pemerintah Daerah dinyatakan bahwa pengertian desentralisasi adalah penyerahan wewenang pemerintahan oleh pemerintah kepada daerah otonom untuk mengatur dan mengurus urusan pemerintahan dalam 
sistem Negara Kesatuan Republik Indonesia. Kemudian Pasal 1 butir 5 UU Nomor 32 Tahun 2004 pengertian otonomi daerah adalah hak, wewenang dan kewajiban daerah otonom untuk mengatur dan mengurus sendiri urusan pemerintahan dan kepentingan masyarakat setempat sesuai dengan peraturan perundangundangan. Sedangkan berdasarkan ketentuan Pasal 1 butir 6 Undang-undang Nomor 32 Tahun 2004 yang dimaksud dengan daerah otonom adalah kesatuan masyarakat hukum yang mempunyai batasbatas wilayah yang berwenang mengatur dan mengurus urusan pemerintahan dan kepentingan masyarakat setempat menurut prakarsa sendiri berdasarkan aspirasi masyarakat dalam Negara Kesatuan Republik Indonesia.

Undang-Undang Nomor 32 tahun 2004 tentang Pemerintahan Daerah dijelaskan bahwa desentralisasi adalah penyerahan wewenang pemerintah pusat kepada daerah untuk mengatur dan mengurus urusan pemerintahan dalam sistim Negara kesatuan Republik Indonesia.

Desentralisasi ini dimaksudkan untuk mewujudkan pemerintahan yang efektif, efisien, pengambilan keputusan dapat dilakukan dengan lebih cepat dan tepat juga untuk antisipasi terhadap permasalahan karena perbedaan letak geografis, demografi, social ekonomi oleh karena lebih memahami aspirasi dan kebutuhan masyarakat serta pelayanan lebih mudah dilakukan ( Sumanto, 2008: ). Menurut Solly Lubis pentingnya desentralisasi bagi Negara adalah dalam rangka efisiensi, kesetaraan politik dan akuntabilitas politik ( M Solly Lubis, 1983: 14).

Kelemahan dari sistim desentralisasi ini adalah: ( Tuti Rahayu, 2009: 13 )

a. Kesenjangan antar daerah

b. Pertumbuhan / perkembangan daerah tidak sama atau seimbang.

c. Belum ada standardisasi dan pengendalian serta potensi disintegrasi (perpecahan) / daerahisme yang berlebihan

Indonesia dengan wilayah yang sangat luas dan jumlah penduduk yang besar heteroginitas yang begitu kompleks tidak mungkin hanya dapat dijalankan oleh pemerintahan dengan sistim terpusat tanpa melibatkan perangkat daerah dan menyerahkan sebagian kewenangan kepada pemerintah daerah ( J. Riwu Kabo, 1991: 33). Mengingat kenyataan wilayah Negara dan kemajemukan yang sudah dikemukakan di atas maka hasrat untuk memberikan kesempatan yang seluasluasnya kepada daerah-daerah dan berbagai kesatuan masyarakat hukum untuk berkembang secara mandiri dalam negara kesatuan Republik Indonesia perlu diberikan landasan hukum yang jelas dan tegas.

di daerah pasca otonomi daerah diberlakukan adalah eksesa dari diberikannya kewenangan yang luas, oleh karenanya perlu dilakukan penyempurnaan perundang-undangan yang berkaitan dengan otonomi daerah termasuk bidang pengawasan dan sangsi apabila terjadi pelanggaran.

\section{Anggaran Pendapatan dan Belanja Daerah} (APBD)

APBD terkait dengan penganggaran daerah. Penganggaran adalah suatu proses menyusun rencana keuangan yaitu pendapatan dan pembiayaan, kemudian mengalokasikan dana ke masing-masing kegiatan sesuai dengan fungsi dan sasaran ke dalam program berdasarkan tugas dan tanggung jawab dari satuan kerja tertentu. Yang dimaksud dengan satuan kerja adalah organisasi pelaksana seperti dinas, kantor, dan lembaga teknis. APBD adalah suatu rencana keuangan tahunan daerah yang ditetapkan berdasarkan Peraturan Daerah tentang Anggaran Pendapatan dan Belanja Daerah. Jadi, APBD adalah model penganggaran pemerintah daerah yang ditetapkan dengan Peraturan Daerah.

APBD mencerminkan program tahunan pemerintah daerah. Dengan melihat APBD masyarakat akan mengetahui apa yang akan dilaksanakan oleh pemerintah daerah dalam tahun berjalan. Sesuai dengan UU Nomor 25 Tahun 1999 APBD harus disusun berdasarkan pendekatan kinerja, performance. Pendekatan kinerja maksudnya out put dan outcomes, hasil, dari penganggaran harus bisa diukur dengan indikator-indikator yang jelas. Misalnya, jika ada anggaran untuk perbaikan jalan dan hasil yang ingin 
dicapai adalah lancarnya perhubungan antara wilayah A dan wilayah B demi meningkatkan kegiatan ekonomi pada wilayah tersebut, maka output dan outcome dari penbangunan jalan tersebut harus bisa diukur dengan jelas : perhubungan antara wilayah A ke B lancar, arus barang komoditi dari wilayah A ke B dan sebaliknya lancar, kegiatan ekonomi masyarakat di kedua wilayah meningkat. Jadi, program tersebut tidak sekedar menghabiskan anggaran.

APBD yang disusun dengan pendekatan kinerja memuat:

a. Sasaran yang diharapkan menurut fungsi belanja

b. Standar pelayanan yang diharapkan dan perkiraan biaya satuan komponen kegiatan yang bersangkutan. Pengembangan standar pelayanan dapat dilaksankan secara bertahap dan harus dilakukan secara berkesinambungan.

c. Bagian pendapatan APBD yang membiayai belanja administrasi umum, biaya operasi dan pemeliharaan, dan belanja modal / pembangunan.

Untuk mengukur kinerja keuangan daerah dikembangkan standar analisis belanja, tolok ukur kinerja, dan standar biaya. Yang dimaksud dengan standar analisis biaya adalah penilaian kewajaran atas beban kerja dan biaya terhadap suatu kegiatan. Yang dimaksud dengan tolok ukur kinerja adalah ukuran keberhasilan yang dicapai pada setiap unit organisasi perangkat daerah. Sedangkan yang dimaksud dengan standar biaya adalah harga satuan unit biaya yang berlaku bagi masing-masing daerah. (Hanif Nurcholis, 2005 : 109).

\section{Korupsi}

Istilah korupsi berasal dan perkataan "Corruption", yang berarti kerusakan. Misalnya dapat dipakai dalam kalimat Naskah Kuno Negara Kartagama ada yang Corrupt (=rusak). Di samping itu perkataan korupsi dipakai pula untuk menunjuk keadaan atau perbuatan yang busuk. Korupsi banyak disangkutkan dengan ketidak- jujuran seseorang dalam bidang keuangan (Sudarto, 1986 : 115).

Secara umum korupsi berhubungan dengan perbuatan yang merugikan kepentingan negara atau masyarakat luas untuk kepentingan pribadi, kelompok atau keluarga tertentu. Menurut Black's Law Dictionary, korupsi adalah : "An act done with an intent to give some adventage inconsistent with official duty and the rights of other. The act of an official or fiduciary person who unlawfully and wrongfully uses his station or character to procure some benefit for himself or for another person,contrary to duty and the rights of other", (Henry Campbell Black, 1990 : 102).

Menurut Alatas, korupsi dapat dibagi dalam tujuh jenis yang berlainan, yaitu :

a.

Korupsi transaktif ("transaktive corruption"). Hal tersebut menunjuk kepada adanya kesepakatan timbal balik antara pihak pemberi dan pihak penerima demi keuntungan kedua belah pihak dan dengan aktif diusahakan tercapainya keuntungan ini oleh kedua-duanya;

b. Korupsi yang memeras ("extortive corruption") adalah jenis korupsi dimana pihak pemberi dipaksa untuk menyuap guna mencegah kerugian yang sedang mengancam dirinya, kepentingannya, atau orang-orang, dan hal-hal yang dihargainya;

c. Korupsi investif ("investive corruption") adalah perilaku korban korupsi

dengan pemerasan. Korupsi adalah dalam rangka mempertahankan diri, seperti pemberian barang atau jasa tanpa ada pertalian langsung dengan keuntungan tertentu, selain keuntungan yang dibayangkan akan diperoleh di masa yang akan datang;

d. Korupsi perkerabatan ("nepotistic corruption") adalah penunjukan yang tidak sah terhadap teman atau sanak saudara untuk memegang jabatan dalam pemerintahan, atau tindakan yang memberi perlakuan yang mengutamakan dalam bentuk uang atau bentuk-bentuk lain, kepada mereka, secara bertentangan dengan norma atau peraturan yang berlaku;

e. Korupsi defensif ("defensif corruption") yaitu pemberi tidak bersalah tetapi si penerima yang bersalah. Misal : seorang penguasa yang kejam menginginkan hak milik seseorang, tidak berdosalah memberikan kepada penguasa tersebut sebagian harta itu untuk menyelamatkan harta selebihnya; 
f. Korupsi otogenik ("autogenic corruption") suatu bentuk yang tidak melibatka orang lain dan pelakunya hanya seorang diri;

g. Korupsi dukungan ("supportive corruption"), yaitu tidak menyangkut uang atau imbalan dalam bentuk lain. Tindakantindakan yang dilakukan adalah untuk melindungi dan memperkuat korupsi yang sudah ada (Alatas, Dalam Nyoman SPJ, $2000: 5$ )

Jack Bologna sebagaimana dikutip

oleh BPKP mengemukakan "Gone Theory" guna menjelaskan faktor-faktor yang menyebabkan kecurangan, yang meliputi : "Greeds" (keserakahan), "Opportunities" (kesempatan), "Needs" (kebutuhan) dan "Exposures" (pengungkapan).

a. Greeds (keserakahan) berkaitan dengan adanya perilaku serakah yang secara potensial ada dalam setiap diri orang;

b. Opportunities (kesempatan) berkaitan dengan keadaan organisasi atau instansi atau masyarakat yang sedemikian rupa, sehingga terbuka kesempatan bagi seseorang untuk melakukan kecurangan terhadapnya;

c. Needs (kebutuhan) berkaitan dengan faktor-faktor yang dibutuhkan oleh individu-individu yang menunjang hidupnya yang wajar;

d. Exposures (pengungkapan) berkaitan dengan tindakan atau konsekuensi yang akan dihadapi oleh pelaku apabila pelaku ditemukan melakukan kecurangan.

Dengan demikian, apabila mengikuti theory : G-O-N-E, maka korupsi akan berkembang apabila faktorfaktor GONE ini kondusif untuk timbulnya korupsi.

Dengan bahasa yang sederhana, apabila pada diri seseorang yang kebetulan memegang jabatan politik, sifat keserakahannya begitu tinggi, keadaan organisasi atau instansi di mana dia bekerja administrasi keuangan tidak teratur dan pengawasan tidak ketat, didukung oleh kebutuhan hidup yang serba mewah disertai pengungkapan perkara oleh aparat penegak hukum tidak

Yustisia Vol.1 No.1 Januari - April 2012 tegas, maka korupsi akan tumbuh dengan suburnya. Sebaliknya apabila seseorang tidak serakah dan ia jujur, organisasi yang serba teratur dan pengawasan berjalan sebagaimana mestinya tidak dengan pola hidup konsumtif dan penegakan hukum yang begitu tegas tanpa pandang bulu, maka niscaya korupsi dapat ditekan. Pada akhirnya ditentukan oleh "hati nurani" (Nyoman Serikat Pj, 2000 : 7).

\section{Metode Penelitian}

Penelitian ini merupakan penelitian kepustakaan dengan mengkaji berkas kasus korupsi APBD Surakarta tahun 1999-2004 dan juga peraturan perundang- undangan terkait. Jenis data yang dipakai dalam penelitian ini tergolong dalam data sekunder yang berupa berkas kasus/ Undang-Undang/peraturan/dokumen/buku, serta hasil penelitian. Teknik pengumpulan data dilakukan dengan cara membaca buku-buku, literatur, peraturan perundang-undangan, dokumendokumen, makalah ilmiah dan hasil penelitian yang ada hubungannya dengan permasalahan yang diteliti. Analisis data menggunakan content analysis atau analisis isi.

\section{Hasil Penelitian dan Pembahasan}

Perda no. 13 tahun 2003 adalah tentang APBD kota Surakarta yang sebelumnya diatur dalam Perda no 1 tahun 2003. Perubahan yang dilakukan meliputi

1. Sektor Pendidikan, Kebudayaan Nasional, Kepercayaan terhadap Tuhan YME, Pemuda dan Olah Raga mengalami kenaikan sebesar $0,92 \%$ atau naik sebesar Rp. 158.000.000,-. Pada sektor ini anggaran semula Rp. 17.146.730.000,- naik menjadi Rp. 17.304.730.000,-.

2. Sektor Kependudukan dan Keluarga Sejahtera hanya mendapat alokasi anggaran sebesar Rp. 90.470.000,- atau mengalami penurunan.

3. Sektor Kesehatan, Peranan Wanita, Anak dan Remaja semula anggaran sebesar Rp. 3.868.089.000,- mengalami penurunan sebesar Rp. 295.016.000,- atau turun menjadi $7,63 \%$ sehingga menjadi Rp. 3.573.073.000,-.

4. Sektor Perumahan dan Pemukiman, anggaran semula sebesar Rp. 850.000.000,menjadi sebesar Rp.

Analisis Perda No 13 Tahun... 26 
370.000 .000 ,- atau turun $43,53 \%$ menjadi Rp. 480.000.000,-.

5. Sektor Agama, tetap seperti semula sebesar Rp. 879.000.000,-

6. Sektor Ilmu pengetahuan dan Teknologi, tetap seperti semula yaitu Rp. 425.000.000,-.

7. Anggaran belanja rutin DPRD Kota Surakarta tahun 2003 sesuai DIKDA (Daftar Isian Kegiatan Daerah) Nomor : 914/016/R/III/2003 tanggal 18 Maret 2003 mengalami perubahan besaran anggaran dari sebesar Rp. 13.092.341.000,menjadi DIKDA Perubahan Nomor : 914/02/Prb/R/XI/2003 tanggal 17 November 2003 sebesar Rp. 16.359.000.000,atau naik sebesar $11,58 \%$.

8. Sektor Kesejahteraan Masyarakat (antara lain Pendidikan, Kesehatan, Kesejahteraan Sosial dan lain sebagainya) dan Perubahan Anggaran Belanja Rutin DPRD Kota Surakarta Tahun 2003, seharusnya lebih banyak alokasi anggaran belanja rutin pada Sektor Kesejahteraan Masyarakat dari pada alokasi anggaran belanja rutin DPRD Kota Surakarta Tahun 2003.

9. Keputusan Pimpinan Dewan Nomor 28A/Pimp.DPRD/IX/2003 yang merubah / menaikkan :

a) Biaya operasional / penunjang kegiatan

b) Belanja barang

c) Uang saku perjalanan dinas yang kesemuanya dituangkan dalam APBD perubahan (Perda No. 13 Tahun 2003).

Pembayaran / Pengeluaran untuk DPRD yang tidak diatur dalam APBD

Dalam Tahun Anggaran 2003 terdapat pengeluaran pembayaran premi asuransi untuk 45 orang DPRD Kota Surakarta sebesar Rp. 780.000.000,- dengan perincian : $45 \mathrm{x}$ Rp. 10.000.000,- = Rp. 450.000.000,44 x Rp. 7.500.000,- = Rp. 330.000.000,-

Rp. 780.000.000,-

Dalam Tahun Anggaran 2003 realisasi pengeluaran anggaran untuk fraksi pada DPRD Kota Surakarta sebesar Rp. 200.000.000,- dengan perincian :

Untuk Fraksi TNI Rp. 40.000.000,Untuk Fraksi Golkar Rp. 40.000.000,-

Untuk Fraksi PDIP Rp. 40.000.000,Untuk Fraksi Pembaharuan Rp. 40.000.000,-

Untuk Fraksi PAN Rp. 40.000.000,Jumlah Rp. 200.000.000,-

Pengeluaran / Pembayaran yang tidak sesuai dengan planning di APBD.

Anggaran Belanja barang untuk ongkos kantor lain-lain digunakan untuk biaya kegiatan sosial kemasyarakatan sebagai berikut :

Setelah dinaikan Rp. 1.141.734.000,-

Seharusnya Rp. 673.500.000,-

Selisih Rp. 468.234.000,-

PPh. Ps. 21 Rp. 40.200.000,-(-)

Rp. 428.034.000,-

Belanja barang untuk ongkos kantor langganan-langganan digunakan untuk membayar biaya bantuan rumah tangga Pimpinan dan Anggota Dewan serta Sekretaris Dewan sebagai berikut :

Pimpinan dan Anggota Dewan Rp. 867.500.000,-

Sekretaris Rp. $\underline{3.300 .000,-}$

Jumlah Rp. 870.800.000,-

Pos belanja barang Rp. 331.500.000,-

Jumlah Rp. 539.300.000,-

PPh Ps. 21 Rp. 80.895.000,-

Kerugian keuangan Negara/daerah Rp. 458.105.000,-

Pembayaran perjalanan dinas tidak sesuai dengan pelaksanaan :

Bambang Mudiarto ke Jakarta Rp. 2.420.000,-

Bambang Mudiarto ke Ambon Rp. 1.200.000,-

H. Siswandi ke Sidoarjo Rp. 1.635.000,-

Jumlah Rp. 5.255.000,-

Pembiayaan anggaran biaya pendidikan yang seharusnya untuk pendidikan, seminar dalam rangka peningkatan SDM dan berdasarkan penugasan yang sah tapi dipergunakan untuk :

Kontribusi penganugrahan citra insan Indonesia 2 yang diterima James A. Pattiwael Rp. 2.500.000,Biaya Wisuda Strata II yang diterima James A. Pettiweal Rp. 14.000.000,-

Jumlah Rp. 16.500.000,-

Analisis Perda No 13 Tahun... 27 
Jumlah kenaikan penghasilan anggota DPRD Kota Surakarta Tahun 2003, yaitu :

Pembiayaan yang sudah ada aturan / ketentuan :

1. Kenaikan biaya Operasional/ penunjang Kegiatan Rp. 1.390.000.000,-

2. Kenaikan belanja barang Rp.

3. Kenaikan biaya perjalanan dinas ke Luar jawa Rp. 93.430.000,-

Jumlah Rp. 2.338.280.000,-

Pembiayaan yang tidak ada dasar / ketentuan :

1. Pembiayaan premi angsuran Rp. 780.000.000,-

2. Anggaran untuk fraksi Rp.

3. Biaya reses Rp. 46.000.000,-

Jumlah Rp. 1.026.000.000,-

Pembayaran yang tidak sesuai dengan peruntukannya

1. Untuk ongkos sosial kemasyarakatan Rp. 428.034.000,-

2. Untuk biaya bantuan rumah tangga Rp. 458.405.000,-

3. Untuk biaya perjalanan dinas Rp. 5.255.000,-

4. Untuk biaya pendidikan Rp.

Jumlah Rp. 908.134.000,-

Jumlah $\quad A+B+C$

4.272.474.000,-

Rp.

Untuk menganalisis apakah perbuatan para anggota DPRD Surakarta periode 1999 - 2004 merubah APBD (menyusun APBD perubahan /UU No. 13 Tahun 2003). Merupakan faktor kriminogen dari suatu tindak pidana korupsi atau tidak maka harus jelas dahulu perbuatan apa saja yang termasuk tindak Pidana Korupsi.

Dalam UU No. 31 Tahun 1999 jo UU No. 20 Tahun 2001 tentang tentang Pemberantasan Tindak Pidana Korupsi, tindak pidana korupsi :

a. Pasal 2 Ayat 1: Setiap orang yang secara melawan hukum melakukan perbuatan memperkaya diri sendiri atau orang lain atau suatu korporasi yang dapat merugikan keuangan negara atau perekonomian Negara.

b. Pasal 3: Setiap orang yang dengan tujuan menguntungkan diri sendiri atau orang lain atau suatu korporasi, menyalahgunakan kewenangan kesempatan atau sarana yang ada padanya kerena jabatan atau kedudukan yang dapat merugikan keuangan Negara.

c. Pasal 5 sampai pasal 12 Setiap orang yang melakukan tindak pidana sebagaimana dimaksud dalam Pasal 209, 210, 387, 388, 415, 416, 418, 419, 420, 423, 425, dan 435 Kitab Undangundang Hukum Pidana.

854.P5Aa000,3 “ Setiap orang yang memberikan hadiah atau janji kepada pegawai negeri dengan mengingat kekuasaan atau wewenang yang melekat pada jabatan atau kedudukannya atau oleh pemberi hadiah atau janji dianggap melekat pada jabatan atau kedudukan".

e. Barang siapa tanpa alasan yang 200jo00.0003tam waktu sesingkatsingkatnya setelah menerima pemberian atau janji yang diberikan kepadanya, seperti yang tersebut dalam pasal 418, 419 dan 420 KUHP tidak melaporkan pemberian atau janji tersebut kepada yang berwajib.

f. Pasal 15 setiap orang yang melakukan percobaan pembantuan atau permufakatan untuk melakukan tindak pidana korupsi, dipidana dengan pidana yang sama sebagaimana 16ifnakd0@, Aalam Pasal 2, Pasal 3 Pasal 5 sampai dengan Pasal 14.

Tindak Pidana Lain Yang Berkaitan dengan Tindak Pidana Korupsi.

a. (Pasal 21) "Setiap orang yang dengan sengaja mencegah, merintangi atau menggagalkan secara langsung atau tidak langsung penyidikan, penuntutuan dan pemeriksaan di sidang terdakwa maupun para saksi dalam perkara korupsi”

b. (Pasal 22) Setiap orang sebagaimana dimaksud dalam pasal 28, Pasal 29, Pasal 35 atau Pasal 36 yang dengan sengaja tidak memberi keterangan atau memberi keterangan yang tidak benar.

c. (Pasal 23) Dalam perkara korupsi, pelanggaran terhadap ketentuan sebagaimana dimaksud dalam Pasal 220, Pasal 231, Pasal 421, Pasal 442, Pasal 429 atau Pasal 430 Kitab Undang-undang Hukum Pidana. 
d. (Pasal 24) Saksi yang tidak memenuhi ketentuan sebagaimana dimaksud dalam Pasal 31.

Untuk mengetahui apakah ada factor kriminogen yang kemudian dapat diklasifikasikan sebagai tindak pidana korupsi oleh anggota DPRD Surakarta periode 1999 - 2004 maka dapat ditelusuri dari proses perubahan APBD maupun keluarnya anggaran (pembayaran) tanpa melalui mekanisme APBD seperti diuraikan. Pimpinan Dewan mengeluarkan surat keputusan melalui mekanisme: Sekretaris mempersiapkan berkas untuk rapat panitia Rumah Tangga kemudian anggota PRT melakukan rapat dan Sekretaris Dewan mencatat hasil rapat PRT untuk dibicarakan dalam Rapat Pimpinan Dewan. Sekretaris Dewan rnembawa catatan hasil rapat PRT sebagai bahan dalam Rapat Pimpinan Dewan, Sekretaris Dewan ikut serta mencatat hasil rapat Pimpinan Dewan. Hasil terakhir diterbitkannya Surat Keputusan Pimpinan Dewan.

Surat Keputusan Pimpinan Dewan tersebut selanjutnya diserahkan ke Panitia Anggaran Pemerintah Kota (Pemkot) Surakarta untuk dilakukan pembahasan oleh Panitia Anggaran (Panggar) Pemkot Surakarta, bersama-sama dengan materi usulan anggaran belanja dari Dinas yang lain, setelah dilengkapi dengan Nota Keuangan dari Walikota, dikembalikan lagi kepada DPRD, untuk dibahas dalam sidang Komisi DPRD, maupun dalam sidang Paripurna DPRD.

Surat Keputusan Pimpinan Dewan tersebut" tidak dilakukan pembahasan oleh Panitia Anggaran Pemkot Surakarta, dengan harapan akan menjadi bahan pembahasan dalam sidang Komisi maupun sidang Paripurna DPRD, namun ternyata dalam sidang Komisi maupun sidang Paripurna DPRD juga tidak dibahas dan langsung disetujui oleh Dewan (DPRD), sehingga keluarlah Surat Keputusan Pimpinan Dewan sebagai berikut :

a. Melakukan perubahan anggaran belanja DPRD Kota Surakarta Tahun 2003, dengan SK No. 28 A/PIMPDPRD/III/2003 tanggal 8 September 2003, berupa perubahan kenaikan biaya/ tarif terhadap biaya sosial kemasyrakatan, bantuan rumah tangga, penetapan Perda, operasional komisi. Bantuan perumahan dan taktis operasional tersebut tidak memperhatikan atau mengabaikan atau menyimpang hal ini dapat dikaji dari :

1) Peraturan Pemerintah Nomor : 105 Tahun 2000 tentang Pengelolaan dan Pertanggungjawaban Keuangan Daerah (pasal 23 ayat 1) dan

2) Surat Edaran Mendagri No. 903/2477/Sj tanggal 5 Desember 2001 perihal Pedoman Umum Penyusunan dan Pelaksanaan APBD dan Keputusan Mendagri No. 29 Tahun 2002 pasal 26 (1) menyatakan perubahan APBD dilakukan sehubungan dengan :

a) Kebijaksan Pemerintah Pusat dan atau Daerah yang bersifat strategis.

b)Penyesuaian akibat tidak tercapainya target penerimaan daerah yang ditetapkan.

c) Terjadinya kebutuhan yang mendesak

Bahwa hal-hal seperti tersebut huruf $a, b$ dan c tersebut tidak nampak dalam pertimbangan SK No. 18 A/PIMPDPRD/II1/2003 yang nampak justru adalah pertimbangan bahwa biaya / tarif SK sebelumnya sudah tidak sesuai lagi.

b.Memberikan premi asuransi dengan mengeluarkan SK No. 28/PIMPDPRD/X/2000 tanggal 10 Oktober 2000 dan SK No. 24 A/PIMP-DPRD/III/2002 tanggal 30 Juli 2002, tidak ada dasarnya karena Perda No. 3 Tahun 2001 tentang Kedudukan Keuangan DPRD Kota Surakarta, tidak mengatur tentang premi asuransi. Pengeluaran anggaran untuk pembayaran asuransi tersebut sematamata kebijakan Pimpinan Dewan.

c.Pengeluaran anggaran biaya operasional untuk bantuan Fraksi, didasarkan pada SK Pimpinan Dewan No. 08/PIMPDPRD/III/2003 tanggal 12 Maret 2003.

Pengeluaran anggaran untuk bantuan Fraksi tidak ada dasar ketentuannya. Perda No. 3 Tahun 2001 tentang Kedudukan Keuangan DPRD Kota Surakarta tidak mengatur biaya operasional untuk fraksi. Pengeluaran anggaran untuk bantuan fraksi sematamata atas kebijakan Pimpinan Dewan.

d.Pengeluaran anggaran untuk membayar biaya bantuan rumah tangga Pimpinan Dewan, anggota Dewan dan Sekretaris Dewan dibayar dengan menggunakan

Analisis Perda No 13 Tahun...

29 
anggaran belanja barang untuk ongkos kantor pos langganan-Ianggan pasal 2.2.1.1011.60, pembayaran tersebut didasarkan pada SK Pimpinan Dewan No. 8/PIMP-DPRD/III/2003 tanggal 12 Maret 2003 dan No. 28 A/PIMP-DPRD/III/2003 tanggal 8 September 2003.

Seharusnya anggaran belanja barang untuk ongkos pos langgananlangganan digunakan untuk pengeluaran rutin seperti pembayaran listrik, telepon dan gas, dengan kwitansi tagihan dari pihak ketiga. Sesuai dengan pasal 55 (2) Keputusan Mendagri No. 29 Tahun 2002, menyatakan bahwa pengguna anggaran dilarang melakukan pengeluaranpengeluaran atas beban belanja Daerah untuk tujuan lain dari pada yang ditetapkan.

e.Pengeluaran anggaran untuk membayar biaya sosial kemasyarakatan, dibayar dengan menggunakan anggaran-anggaran belanja barang untuk Pos lain-lain pasal 2.2.1.1011.90, hal tersebut didasarkan atas kebijakan Pimpinan Dewan dengan SK No. 8/PIMP-DPRD/III/2003 tanggal 12 Maret 2003 dan SK No. 28 A/PIMPDPRD/IX/2003 tanggal 8 September 2003.

Sesuai dengan pasal 55 (2) Keputusan Mendagri No. 29 Tahun 2002, menyatakan bahwa Pengguna Anggaran dilarang melakukan pengeluaranpengeluaran atas beban Belanja Daerah untuk tujuan lain dari pada yang ditetapkan.

f. Undang-Undang R.I. Nomor : 17 Tahun 2003 tentang Keuangan Negara, pasal 26 ayat (2) yang berbunyi antara lain bahwa setelah APBD ditetapkan dengan Peraturan Daerah, pelaksanaannya dituangkan lebih lanjut dengan Keputusan Gubernur / Bupati / Walikota.

g. Undang-Undang R.I. Nomor : 22 Tahun 1999 tentang Otonomi Daerah, pasal 70 yang berbunyi antara lain bahwa Peraturan Daerah tidak boleh bertentangan dengan kepentingan umum, peraturan daerah lain dan peraturan perundang-undangan yang lebih tinggi dan pasal 27 ayat 1 yang menyatakan bahwa untuk melaksanakan peraturan daerah (Perda), maka Kepala Daerah akan menetapkan Keputusan Kepala Daerah.

h. Peraturan Pemerintah Nomor : 105 Tahun 2001 tentang Pengelolaan dan Pertanggungjawaban Keuangan Daerah, pasal 35 yang berbunyi antara lain
Tindakan yang mengakibatkan pengeluaran atas beban APBD tidak dapat dilakukan sebelum ditetapkan dalam Peraturan Daerah tentang APBD.

Dari uraian diatas jelas behwa pebuatan pimpinan dan anggota dewan DPRD Surakarta periode 1999-2004 melanggar pasal 2 dan pasal 3 UU No. 31 Tahun 1999 sebagaimana diubah dan ditambah dengan UU No. 20 Tahun 2001 tentang Tindak Pidana Korupsi yaitu :

Pasal 2 (1)

Setiap orang yang secara melawan hukum melakukan perbuatan memperkaya diri sendiri atau orang lain atau suatu korporasi yang dapat merugikan keuangan negara atau perekonomian negara.

Pasal 3

Setiap orang yang dengan tujuan menguntungkan diri sendiri atau orang lain atau suatu korporasi menyalah gunakan kewenangan, kesempatan atau sarana yang ada padanya karena jabatan atau kedudukan yang dapat merugikan keuangan negara atau perekonomian negara.

\section{E. Simpulan}

Berdasarkan hasil penelitian dan pembahasan, maka disimpulkan :

1. Perda NO 13 tahun 2003 tentang APBD adalah merupakan perubahan terhadap APBD yang sebelumnya diatur dalam Perda NO. 1 Tahun 2003. Perubahan yang dilakukan meliputi anggaran sektor:

a.Pendidikan, Kebudayaan, Kepercayaan terhadap Tuhan YME Pemuda dan Olah Raga anggaran mengalami kenaikan.

b.Kependudukan dan Keluarga Sejahtera anggaran diturunkan.

c. Kesehatan anggaran diturunkan.

d.Perumahan dan pemukiman anggaran mengalami penurunan.

e.Belanja rutin DPRD anggaran dinaikkan.

f. Kesra anggaran diturunkan.

g.Uang saku perjalanan dinas anggarannya dinaikkan.

h.Belanja barang anggaran dinaikkan

2. Perda NO 13 tahun 2003 tentang APBD yang merubah Perda NO 1 Tahun 2003 terdapat faktor kriminogen yang memenuhi unsur-unsur pidana tindak korupsi khususnya melanggar Pasal 2 (1) dan Pasal 3 UU NO 31 Tahun 1999 Jo UU NO 20 Tahun 2001 tentang Tindak Pidana Korupsi karena kesalahan dalam proses perubahan APBD maupun tidak adanya dasar hukum dalam penentuan anggaran maupun pengeluaran anggaran sektor 
tertentu sebagaimana disampaikan dalam BAB IV.

\section{F. Saran}

Berdasarkan simpulan di atas disarankan perlunya diadakan suatu penataran bagi anggota
DPRD (legislatif) dan eksekutif kabupaten/ kota tentang hak dan kewajiban anggota DPRD, tugas dan wewenang serta fungsi, dan pengetahuan hukum. 


\section{Daftar Pustaka}

Henry Campbell Black. 1990. Black Law Dictionary - : ST Paul Nim West Publising.

Hanif Nurcholis. 2005. Otonomi Daerah. Jakarta: Gramedia.

Josep Riwu Kabo. 1991. Prospek Otonomi Daerah di Negara RI. Jakarta: Rajawali Press.

M. Solly Lubis. 1983. Pergeseran Garis Politik dan Perundang-undangan Mengenai Pemerintah Daerah. Bandung : Alumni

Nyoman Serikat PJ. 2000. Tindak Pidana KKN. Semarang: BP. Undip.

Pieter Mahmud Marjuki. 2005. Penelitian Hukum. Jakarta: Kencana Prenada Media Group.

Soerjono Soekanto. 1985. Penelitian Hukum Normatif. Jakarta: Raja Grafindo Persada.

Sudarto. 1986. Hukum dan Hukum pidana. Bandung : Alumni

Sumanto. 2008. Hukum administrasi dan Desentralisasi. Surakarta Materi Kuliah Pasca Sarjana. UNS.

Tjejep Rohendi. 1992. Pengantar penelitian kualitatif. Jakarta: Gramedia.

Tuti Rahayu. 2009. Penelitian Perda No 07 tahun 2002 tentang Pajak Pengambilan Air Bawah Tanah di Dinas Pendapatan dan Pengelola Aset Daerah Jawa Tengah. Surakarta : Tesis Setneg.

Undang-undang Republik Indonesia No 32 tahun 2004 tentang Otonomi Daerah. Jakarta:

Undang-Undang No 25 tahun 2004 tentang Perencanaan Pembangunan Nasional. Jakarta : Setneg.

. Undang-Undang No 17 tahun 2003 tentang Keuangan Negara. Jakarta: Setneg.

. Undang-Undang No 31 tahun 1999 jo Undang-Undang No 20 tahun 2001 tentang Tindak Pidana Korupsi. Jakarta: Setneg.

. Peraturan Pemerintah No 105 tahun 2000 tentang Pengelolaan dan Pertanggungjawaban Keuangan Daerah. Jakarta: Setneg.

Perda No 13 tahun 2003 tentang APBD Kota Surakarta. 